\title{
ВПЛИВ ФАКТОРА СПАДКОВОСТІ НА РОЗВИТОК ПЕРВИННОЇ АРТЕРІАЛЬНОЇ ГІПЕРТЕНЗІї У ПАЦІЄНТІВ МОЛОДОГО ВІКУ
}

\author{
๑Т. А. Іваницька, Ю. Г. Бурмак, І. В. Іваницький
}

Вищий державний навчальний заклад України «Українська медична стоматологічна академія»

РЕЗЮМЕ. Останнім часом зростає поширеність есенціальної артеріальної гіпертензії (АГ) у пацієнтів молодого віку. Водночас, у порівняно великого відсотка цих пацієнтів наявні окремі компоненти метаболічного синдрому (МС).

Мета дослідження - визначення сімейної спадковості щодо окремих компонентів МС та їх впливу на розвиток АГ у пацієнтів молодого віку.

Було обстежено 56 пацієнтів молодого віку, 26 осіб жіночої та 30 - чоловічої статі, з проявами есенціальної АГ. Середній вік обстежених склав 23,5 22,4 роки. Нами було проведене анкетування цих пацієнтів з метою виявлення захворювань-маркерів, таких як діабет 2 типу, абдомінальне ожиріння (АО), АГ, атеросклеротичні ураження судин, включаючи ішемічну хворобу серця (IXC), наявність в анамнезі гострих порушень мозкового кровообігу (ГПМК) та інфаркту міокарда (IM), подагричного артиту та безсимптомної гіперурикемії у найближчих родичів. Кожне перераховане захворювання давало 1 бал, результат оцінювали за сумою балів. Після аналізу отриманих даних ми виявили, що діабет 2 типу в родинному анамнезі був у 21 пацієнта (38 \%), АГ -у 41 пацієнта (73\%), АО -у 20 пацієнтів (36 \%), атеросклеротичні ураження судин - у 36 пацієнтів (64 \%), ГПМК та IM - у 21 пацієнта (38 \%), подагричний артрит та безсимптомна гіперурикемія - у 10 пацієнтів (18\%). За даними кореляційного аналізу відмічався зв'язок між ступенем вираженості АГ та кількістю балів, набраних за опитувальниками ( $r=0,769, p=0,326)$.

Висновки. Спадковість має значну роль у розвитку первинної АГ у пацієнтів молодого віку, тому існує необхідність у проведенні подальшого аналізу генетичних факторів, які можуть впливати на розвиток окремих компонентів МС у хворих на АГ молодого віку.

КЛЮчОВІ СлОВА: первинна артеріальна гіпертензія; молодий вік; спадковість; метаболічний синдром.

Вступ. Останнім часом зростає поширеність есенціальної артеріальної гіпертензії (АГ) у пацієнтів молодого віку. Відомо, що високий артеріальний тиск (АТ) ( $\geq 140 / 90$ мм рт. ст.) безпосередньо пов'язаний зі смертністю від серцево-судинних захворювань (ССЗ) і загальною летальністю, та $\epsilon$ найвагомішим незалежним модифікованим фактором ризику TIA/інсульту [1]. Результати багатьох досліджень свідчать про найбільший самостійний внесок у популяційний серцево-судинний ризик саме підвищеного АТ [2]

Останнім часом з'являються дані щодо помолодшання дебюту артеріальної гіпертензії, відомо, що серед дітей АГ виявляється в 6-14 \% від усіх обстежених, а у підлітків - в 4-18 \% [3]. Досить часто артеріальна гіпертензія $є$ компонентом метаболічного синдрому. Водночас, у порівняно великого відсотка цих пацієнтів спостерігається наявність окремих компонентів метаболічного синдрому (MC). Поширеність МС серед підлітків з ожирінням становить 53 \%, у 24,5 \% з них відмічається тяжка форма захворювання з наявністю 6 діагностичних критеріїв МС [4]. За даними клінічних рекомендацій з артеріальної гіпертензії Європейського товариства гіпертензії та Європейського товариства кардіологів 2013 р., серцево-судинний ризик може бути вищим у пацієнтів із малорухливим способом життя, а також у пацієнтів із центральним ожирінням; збільшення відносного ризику пов'язане з надмірною вагою і більш значиме в молодих лю- дей, ніж у літніх осіб. Водночас, у порівняно великого відсотка цих пацієнтів спостерігається наявність окремих компонентів метаболічного синдроMy (MC).

Мета дослідження - визначення сімейної спадковості щодо окремих компонентів МС та їх впливу на розвиток АГ у пацієнтів молодого віку.

Матеріал і методи дослідження. Було обстежено 56 пацієнтів молодого віку, 26 осіб жіночої та 30 - чоловічої статі, з проявами есенціальної АГ. Середній вік обстежених склав $(23,5 \pm 2,4)$ роки. Нами було проведене анкетування цих пацієнтів 3 метою виявлення захворювань - маркерів, таких як діабет 2 типу, абдомінальне ожиріння (АО), АГ, атеросклеротичні ураження судин, включаючи ішемічну хворобу серця (IXC), наявність в анамнезі гострих порушень мозкового кровообігу (ГПМК) та інфаркту міокарда (IM), подагричного артиту та безсимптомної гіперурикемії у найближчих родичів, кожне перераховане захворювання давало 1 бал, результат оцінювали за сумою балів.

Для комп'ютерної статистичної обробки даних використовувався табличний редактор "Місгоsoft Excel" та програму статистичного аналізу Analyst Soft Stat Plus. Для аналізу нормальності розподілу отриманих даних використовували критерії Ліллієфорса та Шапіро -Уїлка з рівнем $p<0,05$. У випадку нормального розподілу даних достовірність різниці між показниками визначали за допомогою t-критерію Стьюдента. Для аналізу кореля- 
Огляди літератури, оригінальні дослідження, погляд на проблему, ювілеї

ційних зв'язків використовували метод Пірсона. У випадку відсутності нормального розподілу досліджуваних даних центральні тенденції та дисперсії досліджуваних ознак описували за допомогою медіани (Ме) та інтерквартильного розмаху (25 та 75 процентилі). Для подальшого дослідження використовували критерії Манна-Уїтні, ВальдаВольфовіца, Колмогорова-Смірнова, для аналізу кореляції використовували методи Спірмена та Кендалла із статистично значимими відмінностями на рівні $р<0,05$.

Результати й обговорення. Після аналізу отриманих даних ми виявили, що діабет 2 типу зустрічався в родинному анамнезі у 21 пацієнта
(38\%), АГ - у 41 пацієнта (73\%), АО - у 20 обстежених (36\%), атеросклеротичні ураження судин - у 36 пацієнтів (64\%), ГПМК та IM - у 21 пацієнта (38\%), подагричний артрит та безсимптомна гіперурикемія - у 10 пацієнтів (18\%). За даними кореляційного аналізу відмічався зв'язок між ступенем вираженості АГ та кількістю балів, набраних за опитувальниками $(r=0,769, p=0,326)$.

Висновки. Спадковість відіграє важливу роль у розвитку первинної АГ у пацієнтів молодого віку, тому існує необхідність у проведенні подальшого аналізу генетичних факторів, які можуть впливати на розвиток окремих компонентів МС у хворих на АГ молодого віку.

\section{ЛІТЕРАТУРА}

1. Ждан В. М. Особливості функціонального стану серцево-судинної системи у хворих з поєднаною серцево-легеневою патологією / В. М. Ждан, В. Ю. Штомпель, І. В. Іваницький // «Наукові та практичні аспекти хронізації неінфекційних захворювань внутрішніх органів» : матеріали науково-практичної конференції з міжнародною участю, 06 листопада 2014 р. - Харків, 2014. - С. 122.

2. Ждан В. М. Артеріальна гіпертензія і цереброваскулярна патологія в загальнолікарській практиці: як покращити прогноз? / В. М. Ждан, Є. М. Кітура, М. Ю. Бабаніна, О. Є. Кітура // Особливості коморбідного перебігу захворювань та їх фармакотерапія в клініці внутрішньої медицини : матеріали науково-практичної конференції 3 міжнародною участю. 05 - 06 жовтня 2017 р. - Чернівці, 2014. - C. 122.

3. Hassink S. G. Evidence for effective obesity treatment: pediatricians on the right track! / S. G. Hassink // Pediatrics.- 2010. - Vol. 125 (2). - P. 387-388.

4. Sex differences in the contributions of visceral and total body fat to blood pressure in adolescence / Z. Pausova, A. Mahboubi, M. Abrahamowicz [et al.] // Hypertension. - 2012. - Vol. 59. - P. 572-579.

\section{REFERENCES}

1. Zhdan, V.M., Shtompel, V.Yu., \& Ivanytskyi, I.V. (2014). Osoblyvosti funktsionalnoho stanu sertsevo-sudynnoi systemy u khvorykh z poiednanoiu sertsevo-lehenevoi patolohiieiu [Features of the functional state of the cardiovascular system in patients with combined cardio-pulmonary pathology]. Naukovi ta praktychni aspekty khronizatsii neinfektsiinykh zakvoriuvan vnutrishnikh orhaniv: Materialy naukovo-praktychnoi konfereneii z mizhnarodnoiu uchastiu Scientific and Practical Aspects of Chronization of Noninfectious Diseases of Internal Organs: Materials of Scientific and Practical Conference with International Participation. Kharkiv [in Ukrainian].

2. Zhdan, V.M., Kitura, Ye.M., Babanina, M.Yu., \& Kitura, O.Ye.(2017). Arterialnahipertenziiaitserebrovaskuliarna patolohiia v zahalnolikarskii praktytsi: yak pokrashchyty prohnoz? [Arterial hypertension and cerebrovascular pa-

thology in general medicine practice: how to improve the outlook?]. Osoblyvostikomorbidnoho perebihuzakhvoriuvan ta yikh farmakoterapiia $v$ klinitsi vnutrishnoi medytsyny: Materialy naukovo-praktychnoi konferentsii z mizhnarodnoiu uchastiu - Peculiarities of Comorbid Diseases Course and Their Pharmacotherapy in the Clinics of Internal Medicine: Materials of Scientific and Practical Conference with International Participation. Chernivtsi [in Ukrainian].

3. Hassink, S.G. (2010). Evidence for effective obesity treatment: pediatricians on the right track! Pediatrics, 125 (2), 387-388.

4. Pausova, Z., Mahboubi, A., \& Abrahamowicz, M. (2012). Sex differences in the contributions of visceral and total body fat to blood pressure in adolescence. Hypertension, 59, 572-579. 


\title{
ВЛИЯНИЕ ФАКТОРА НАСЛЕДСТВЕННОСТИ НА РАЗВИТИЕ ПЕРВИЧНОЙ АРТЕРИАЛЬНОЙ ГИПЕРТЕНЗИИ У ПАЦИЕНТОВ МОЛОДОГО ВОЗРАСТА
}

\author{
○Т. А. Иваницкая, Ю. Г. Бурмак, И. В. Иваницкий \\ Высшее государственное учебное заведение Украины «Украинская медицинская \\ стоматологическая академия»
}

\begin{abstract}
РЕЗЮМЕ. В последнее время растет распространенность эссенциальной артериальной гипертензии (АГ) у пациентов молодого возраста. В то же время, у сравнительно большого процента этих пациентов наблюдается наличие отдельных компонентов метаболического синдрома (МС).

Цель исследования - определение семейной наследственности по отдельным компонентам МС и их влияния на развитие АГ у пациентов молодого возраста.

Было обследовано 56 пациентов молодого возраста, 26 лиц женского и 30 - мужского пола, с проявлениями эссенциальной АГ. Средний возраст обследованных составил 23,5 + 2,4 года. Нами было проведено анкетирование этих пациентов с целью выявления заболеваний-маркеров, таких как сахарный диабет 2 типа, абдоминальное ожирение (АО), АГ, атеросклеротические поражения сосудов, включая ишемическую болезнь сердца (ИБС), наличие в анамнезе острых нарушений мозгового кровообращения (ОНМК) и инфаркта миокарда (ИМ), подагрического артита и бессимптомной гиперурикемии у ближайших родственников, каждое перечисленное заболевания давало 1 балл, результат оценивали по сумне балов. После анализа полученных данных мы выявили, что диабет 2 типа встречался в семейном анамнезе у 21 пациента (38 \%), АГ-у 41 пациента (73\%), АО - у 20 пациентов (36 \%), атеросклеротические поражения сосудов - у 36 пациентов (64 \%), ОНМК и ИМ - у 21 пациента (38 \%), подагрический артрит и бессимптомная гиперурикемия - у 10 пациентов (18 \%). По данным корреляционного анализа отмечалась связь между степенью выраженности АГ и количеством баллов, набранных по опроснику $(r=0,769, p=0,326)$.
\end{abstract}

Выводы. Наследственность играет значительную роль в развитии первичной АГ у пациентов молодого возраста, поэтому существует необходимость проведения дальнейшего анализа генетических факторов, которые могут влиять на развитие отдельных компонентов МС у больных АГ молодого возраста.

КЛючЕВыЕ СЛОВА: первичная артериальная гипертензия; молодой возраст; наследственность; метаболический синдром.

\section{INFLUENCE OF THE FACTOR OF HEREDITY ON THE DEVELOPMENT OF PRIMARY ARTERIAL HYPERTENSION IN YOUNG AGE PATIENTS}

\author{
@T. A. Ivanytskaya, Yu. G. Burmak, I. V. Ivanytsky \\ State Higher Educational Institution of Ukraine "Ukrainian Medical Stomatological Academy"
}

SUMMARY. Recently the prevalence of essential hypertension $(E H)$ in young patients has increased. At the same time, a relatively high percentage of these patients has the presence of certain components of the metabolic syndrome (MS).

The aim of our study - to determine the family inheritance of individual components of the MS and their impact on the development of hypertension in young patients.

It was examined 56 young patients, 26 female and 30 male with manifestations of essential hypertension. The average age of the surveyed patients was $(23.5 \pm 2.4)$ years. We have been interviewing these patients for the purpose of identifying diseases - markers such as type 2 diabetes, abdominal obesity (AO), hypertension, atherosclerotic vascular disorders, including coronary heart disease (CHD), history of acute cerebrovascular accident (ACVA), and myocardial infarction (MI), gouty arthritis and asymptomatic hyperuricemia in the relatives. Each of these diseases gave 1 point, in the end the balls were added. After analyzing the data, we found that type 2 diabetes occurred in a family history of 21 patients (38\%), hypertension - in 41 patients (73\%), AO - in 20 patients (36\%), atherosclerotic vascular lesions - in 36 patients (64\%), GPMK and IM - in 21 patients (38\%), gouty arthritis and asymptomatic hyperuricaemia - in 10 patients (18\%). According to the correlation analysis, there was a correlation between the degree of severity of hypertension and the number of points scored on the questionnaires $(r=0.769, p=0.326)$.

Conclusion. The role of heredity in the development of primary hypertension in young patients is significant. It is necessary to do further analysis of genetic factors that may influence the development of individual components of the MS in patients with hypertension in young adults.

KEY WORDS: primary arterial hypertension; young age; heredity; metabolic syndrome. 